Canadian Science Publishing

Canadian Journal of Earth Sciences Revue canadienne des sciences de la Terre

\title{
Wenlock-Ludlow boundary interval revisited: New insights from the off-shore facies of the Prague Synform, Czech Republic
}

\begin{tabular}{|r|l|}
\hline Journal: & Canadian Journal of Earth Sciences \\
\hline Manuscript ID & cjes-2015-0161.R1 \\
\hline Manuscript Type: & Article \\
\hline Date Submitted by the Author: & 07-Dec-2015 \\
\hline Complete List of Authors: & $\begin{array}{l}\text { Storch, Petr; Institute of Geology, CAS } \\
\text { Manda, Štěpán; Czech Geological Survey } \\
\text { Slavík, Ladislav; Institute of Geology, CAS } \\
\text { Tasáryová, Zuzana; Czech Geological Survey }\end{array}$ \\
\hline Keyword: & $\begin{array}{l}\text { Silurian, graptolite, stratigraphy, Wenlock-Ludlow boundary, } \\
\text { Bohemograptus }\end{array}$ \\
\hline
\end{tabular}

\section{SCHOLARONE" \\ Manuscripts}


1 Wenlock-Ludlow boundary interval revisited: New insights from the off-shore facies of

2 the Prague Synform, Czech Republic

3

4 Petr Štorch, Štěpán Manda, Ladislav Slavík, and Zuzana Tasáryová

5

6 P. Štorch. Institute of Geology of the Czech Academy of Science, v.v.i., Rozvojová 269, 165

700 Praha 6, Czech Republic. (storch@gli.cas.cz, +420-233087261).

$8 \quad$ S. Manda. Czech Geological Survey, Klárov 3, 11821 Praha 1, Czech Republic.

9 (stepan.manda@geology.cz).

10 L. Slavík. Institute of Geology of the Czech Academy of Science, v.v.i., Rozvojová 269, 165

1100 Praha 6, Czech Republic. (lavik@gli.cas.cz).

(zuzana.tasaryova@gli.cas.cz).

14

Corresponding author: P. Štorch (storch@gli.cas.cz). 
27 Abstract: Wenlock-Ludlow boundary beds exposed near Nesvačily in the Prague Synform

are documented in terms of their lithology, faunal content, high-resolution record of 19 graptolite species, graptolite biostratigraphy and conodont record. This is the first time in Bohemia and peri-Gondwanan Europe that a continuous graptolite-bearing section through upper ludensis-middle nilssoni biozones is described in detail in order to refine highresolution biostratigraphy and correlation of the Wenlock-Ludlow boundary. Organic-rich shale, relatively rare non-graptolite fauna and absence of bioturbation indicate a stable deepwater off-shore setting with sporadic, low level bottom oxygenation. The uninterrupted succession revealed a series of origination events of principal graptolite taxa employed in determination of the Wenlock-Ludlow boundary strata world-wide. Bohemograptus represented by B. praecox appeared as early as in the uppermost Wenlock ludensis Biozone. B. praecox is later accompanied and replaced by $B$. bohemicus, associated with Uncinatograptus uncinatus. The lowest Neodiversograptus nilssoni marked the base of the Ludlow nilssoni Biozone. Speciation within Bohemograptus continued in the middle nilssoni Biozone when the robust B. butovicensis evolved from B. bohemicus. Colonograptus colonus shows its lowest occurrence in the middle part of the nilssoni Biozone together with the latest C. gerhardi. The monograptids are associated with abundant and diverse plectograptids that are at present mostly known from Baltica. B. praecox sp. nov. and B. butovicensis (Bouček, 1937) are described in the systematic part. The conodont Kockelella ortus absidata, found in the lower-middle part of the nilssoni Biozone, is consistent with a stratigraphic interval within Oz. bohemica and K. crassa conodont biozones. Silurian, graptolite, stratigraphy, WenlockLudlow boundary, Bohemograptus.

Key words: Silurian, graptolite, Stratigraphy, Wenlock-Ludlow boundary, Bohemograptus 


\section{Introduction}

Silurian series and stages belong among the first chronostratigraphic units defined by

Global Boundary Stratotype Section and Point (Holland and Bassett 1989). The GSSP of the

Ludlow Series (and Gorstian Stage) has been placed at the base of Lower Elton Formation at

Pitch Coppice in Shropshire, England. The only biostratigraphically important fossils

recovered from the boundary interval are two fragmentary and poorly preserved graptolite rhabdosomes tentatively assigned to Saetograptus varians (Wood) and Neodiversograptus nilssoni (Lapworth), (White 1981). Despite such limited evidence it has been generally accepted that the "golden spike" at the base of the Lower Elton Formation lies at or close to the base of Neodiversograptus nilssoni graptolite Biozone (Holland and Bassett 1989). widely correlatable changes in microfaunas occur at the boundary" in this GSSP. It must be noted that $S$. varians is confined to the stratigraphically higher Lobograptus progenitor Biozone where it co-occurs with the uppermost populations of N. nilssoni according to our unpublished records from the Všeradice and Bykoš sections. Despite these uncertainties, the nilssoni Biozone is taken as the formal basal biostratigraphic unit of the Ludlow Series and its Gorstian Stage.

Kř́žž et al. (1993) described in detail all accessible sections across the Wenlock-Ludlow boundary in the Prague Synform. Most of these sections preserved the boundary interval in the volcanic-carbonate facies, which yielded a limited and discontinuous graptolite record. Shale-dominated Wenlock-Ludlow boundary strata in the Všeradice section (Krríž et al. 1993), with its relatively good graptolite record described by Kozlowska et al. (2001), are weathered, condensed and interrupted by prominent intervals of pyroclastic deposition. 
77

The Wenlock-Ludlow boundary strata exposed by a trench near Nesvačily in the southwestern part of the Silurian outcrop of the Prague Synform (Fig. 1), yielded a robust and continuous graptolite record comprising 19 species (Fig. 2). The boundary strata, assigned to the upper ludensis and lower-middle nilssoni graptolite biozones, are documented in this paper in terms of their lithology, faunal content, and graptolite and conodont record. This is the first record of a continuous graptolite-rich section through the Wenlock-Ludlow boundary in Central Bohemia and peri-Gondwanan Europe, providing the possibility of refining current high-resolution biostratigraphic dating and correlation of the Wenlock-Ludlow boundary interval.

The data obtained improved our insight in the earliest Ludlow graptolite radiation and succession of origination events close to the Wenlock-Ludlow boundary. The systematic part deals with new material, which sheds more light on the early evolution of Bohemograptus, perhaps one of the most iconic Ludlow graptolites. The oldest known record of Bohemograptus from the uppermost Wenlock ludensis Biozone -B. praecox sp. nov. and the new morphotype represented by the so far enigmatic $B$. butovicensis from the middle nilssoni Biozone are described.

\section{Stratigraphy of the Nesvačily section}

The section exposed a $700 \mathrm{~cm}$-thick shale-dominated succession of the most offshore facies of that time preserved in the Prague Synform. The lowermost $200 \mathrm{~cm}$-thick part of the section consists of dark-grey, distinctly laminated, calcareous shales of the Motol Formation. Common graptolites are associated with fragments of non-vascular plants, fecal pellets, sponge spicules and sporadic pelagic cephalopods. Higher up, the section continues with a $500 \mathrm{~cm}$ thick light-grey, finely laminated, calcareous shales of the Kopanina Formation 
102

interbedded with several 5-20 cm-thick yellow-grey pyroclastic intervals. A $20 \mathrm{~cm}$-thick bed of muddy skeletal limestone is developed $445 \mathrm{~cm}$ above the base of the section (Fig. 2 , sample 545-565). The graptolite-rich shales yielded other fossils including pelagic cephalopods, ostracods, non-vascular plants, rare epibyssate cardiolid bivalves, epiplanktic anthozoan Kolihaia, a.o. The abundance of non-graptolite fossils increases upwards in the Kopanina Formation. Taken together, the section studied corresponds to a deep-water offshore setting with low and occasional bottom oxygenation. In contrast to coeval sections in the Prague Synform, the Wenlock-Ludlow boundary interval is only slightly influenced by volcanism in the Nesvačily section. The pyroclastic deposits are intensely recrystallized by calcite and represent a distal facies of pyroclastic surges and fallouts. Limited portions of volcaniclastic rocks and the relatively thick shale succession of the interval studied indicate a high local subsidence rate that archived an exceptionally high-resolution record of graptolites across the Wenlock-Ludlow boundary.

The lowermost $220 \mathrm{~cm}$ thick part of the Nesvačily section, which is late Homerian (Wenlock) in age, is assigned to the upper part of Colonograptus ludensis Biozone, although dominated by its closely related species C. gerhardi (Kühne). The succeeding Ludlow strata $(480 \mathrm{~cm})$ are assigned to the earliest Gorstian Neodiversograptus nilssoni Biozone, defined by the lowest occurrence of its name-giving taxon. The rather robust record of 19 graptolite species sheds more light on little-known details of the graptolite succession during the postlundgreni radiation culminating in the Wenlock-Ludlow boundary interval. Several graptolite genera typical of Ludlow graptolite faunas (Bohemograptus, Neodiversograptus, Uncinatograptus and advanced Colonograptus ancestral to Saetograptus) originated in this stratigraphic interval and our data show a succession of these origination events (Fig. 2). The earliest, gracile Bohemograptus praecox sp. nov. appears in the upper ludensis Biozone, well before the first $N$. nilssoni (Lapworth). Uncinatograptus uncinatus (Tullberg) made its lowest 
127 occurrence considerably higher, but still preceded the first Colonograptus colonus (Barrande)

128 and Bohemograptus butovicensis (Bouček), both of which made their debut as high as the

129 middle nilssoni Biozone. The long-time enigmatic B. butovicensis - a robust, polonograptid-

130 like Bohemograptus - is limited to a narrow interval in the middle part of the biozone. The

131 partly bleached calcareous shale of the Nesvačily section has also preserved diverse

132 plectograptines, for the most part previously unknown from the Prague Synform

133 [Neogothograptus eximinassa Maletz, Ng. balticus (Eisenack), Ng. ornatus Maletz,

134 Plectograptus robustus (Obut and Zaslavskaya), Pl. macilentus (Törnquist), Spinograptus

135 spinosus (Wood), Sp. clathrospinosus (Eisenack), and Valentinagraptus aff. simplex Piras]

136 (Figs. 3, 4).

137 A conodont fauna has been recorded in a single limestone bed in the lower-middle part of 138 the nilssoni Biozone (Fig. 2, sample 545-565). The recovered conodonts contain Kockelella 139 ortus absidata Barrick and Klapper, which represents an index taxon of the latest Homerian 140 conodont Biozone in the global scale (Calner and Jeppsson 2003). The taxon, however, has a 141 longer stratigraphic range (Homerian-Gorstian) as has been proved from the Prague Synform 142 where it defines a Subzone within the late Homerian Ozarkodina bohemica Interval Zone 143 (Slavík 2014). Because the taxon crosses the Wenlock-Ludlow boundary, it indicates an age

between $O z$. bohemica and $K$. crassa conodont biozones; the latter corresponding to the $N$. nilssoni graptolite Biozone. Associated conodont elements are mostly fragmentary and belong to a spathognathodontid apparatus. Simple cone elements are represented by Panderodus unicostatus (Branson and Mehl) and Dapsilodus obliquicostatus (Branson and Mehl).

\section{Systematic palaeontology}


151

152

153

154

155

156

157

158

159

160

161

162

163

164

165

166

167

168

169

170

171

172

173

174

175

The specimens studied are from P. Štorch's collection housed in the Czech Geological Survey, Prague (prefix PŠ) except for the types of Bohemograptus butovicensis (Bouček), which are housed in the National Museum, Prague (prefix L). Abbreviations: 2TRD - two thecae repeat distance, DVW - dorso-ventral width of the rhabdosome, th - theca.

Bohemograptus butovicensis (Bouček, 1936)

Figures 4N, Q, W; 5A, C

1936 Monograptus butovicensis n. sp., Bouček, pp 4-5, pl. 1, figs 6, 7.

1983 Polonograptus butovicensis (Bouček), Přibyl, pl. 2, fig. 1; pl. 3, fig. 1.

Holotype: By original designation, specimen L 17753 figured by Bouček (1936, pl. 1, fig. 6)

and refigured by Přibyl (1983, pl. 3, fig. 1), from the N. nilssoni Biozone at Praha-Butovice, Bohemia.

Material: More than twenty flattened specimens including immature and incomplete rhabdosomes along with ten complete mature rhabdosomes, holotype L 17753 and paratype L 19968.

Diagnosis: Robust, regularly ventrally curved rhabdosome forming almost complete whorl when mature. Proximal part of B. bohemicus type; sicula ventrally curved, with rutellum. Thecal length and overlap rapidly increase in the mesial part. Distal part more than $2 \mathrm{~mm}$ wide, composed by ca $4 \mathrm{~mm}$ long, relatively slender ventrally curved thecae overlapping for at least three-quarters of their length. 
176 Description: The ventral curvature of the robust rhabdosome, slightly accentuated in the

177 proximal part, forms an almost complete circle in mature, about $100 \mathrm{~mm}$-long specimens. The

178 rhabdosome widens from $0.45-0.6 \mathrm{~mm}$ at theca 1 , through $0.5-0.7 \mathrm{~mm}$ at th $3,0.6-0.85 \mathrm{~mm}$

179 at th 5 to $0.9-1.2 \mathrm{~mm}$ at th 10 . The dorso-ventral width (DVW) further increases through

$180 \quad 1.35-1.9 \mathrm{~mm}$ at th 20 to distal maxima of $1.7-2.2 \mathrm{~mm}(2.5 \mathrm{~mm}$ recorded in one $>120 \mathrm{~mm}$

181 long rhabdosome). The sicula is $1.3-1.7 \mathrm{~mm}$, long, ventrally curved, $0.28-0.35 \mathrm{~mm}$ wide at

182 the aperture, which is furnished with a tiny virgella and more or less prominent rutellum. The

183 sicular apex attains a level either slightly below or slightly above the first thecal aperture. Th1

184 is $1.05-1.15 \mathrm{~mm}$ long, having a concave ventral wall and an even, slightly everted aperture.

185 The following thecae are simple, ventrally curved tubes with perpendicular or slightly everted

186 apertures, overlapping for max. half of their length at th 5, half to two-thirds at th 10, and

187 more than two-thirds at th 20. Distal thecae $4.0-4.3 \mathrm{~mm}$ long, and overlap for about three-

188 quarters of their length. Two-thecae repeat distance (2 TRD) increases from 1.45-1.9 mm at th

1892 , through $1.8-2.0 \mathrm{~mm}$ at th 10 to $1.9-2.3 \mathrm{~mm}$ in distal thecae of mature specimens.

Discussion: The species “Monograptus” butovicensis was established upon two distal parts of mature rhabdosomes preserved in relief in a muddy limestone. Both types originated from a highly fossiliferous, $100 \mathrm{~cm}$-thick bed of shale with abundant limestone nodules exposed at

Barrande's classic locality Butovice in Praha-Jinonice. Associated graptolites included abundant Colonograptus colonus (Barrande), C. roemeri (Barrande), Uncinatograptus uncinatus (Tullberg), and rare fragments referred to Neodiversograptus nilssoni (Lapworth).

197 The generic assignment of "M." butovicensis remained doubtful until this study due to the absence of the proximal part of the rhabdosome. Despite incomplete preservation, " $M$." butovicensis was used as the type species of Polonograptus Tsegelnyuk, 1976 before Urbanek and Teller (1997) suggested that Polonograptus podoliensis Tsegelnyuk should be designated 
201

202

203

204

205

206

207

208

209

210

211

212

213

214

215

216

217

218

219

220

221

222

223

224

225

as a type species of the genus instead of "M." butovicensis (see Riva et al. 2001). Urbanek and Teller (1997) proposed that “M.” butovicensis might be a „preservational species“ representing deformed distal fragments of C. roemeri, which, however, never exhibits such overlapping and ventrally curved thecae.

The present specimens of "M." butovicensis from the Nesvačily section provided undoubted evidence of its Bohemograptus affiliation. The ventrally curved sicula with rutellum, and straight, rather short proximal thecae overlapping for up to half of their length match well those of the type species Bohemograptus bohemicus (Barrande). Distal of about th 10 , the thecal length and overlap regularly increase, finally resulting in the very robust, ventrally curved distal part of the rhabdosome composed of $c a 4 \mathrm{~mm}$ long, relatively slender, ventrally curved thecae overlapping for at least three-quarters of their length. Bohemograptus butovicensis likely represents an early, morphologically distinct offshoot from the longranging $B$. bohemicus lineage.

Extremely robust bohemograptid rhabdosomes recorded in a narrow time slice in about the middle part of the early Gorstian nilssoni Biozone represent the earliest occurrence of a specific morphotype combining a robust, ventrally curved rhabdosome and long, strongly overlapping, ventrally curved thecae. Analogous morphology developed in the thin-walled egregiograptids with an extremely long th 1, confined to the upper Gorstian and lower Ludfordian (Koren'and Sujarkova 2004, Štorch et al. 2014), and finally in the lower and middle Ludfordian polonograptids - the third and stratigraphically youngest group distinguished by a short th 1 and much elongated subsequent thecae of a rapidly widening rhabdosome (Koren` and Sujarkova 2004, Manda et al. 2012). Polonograptids vanished during the late Ludfordian kozlowskii Extinction Event along with all other ventrally curved monograptids. Independent acquisition of a ventrally curved rhabdosome and long overlapping, ventrally curved thecae in three lineages of Ludlow graptolites can be ascribed to 
adaptive convergence.

Bohemograptus praecox sp. nov.

Figures 4L, O-P; 5B, D-E

Holotype: Specimen PŠ 3773 figured on Fig. 5B from the upper ludensis Biozone (Sample 160-180) at the Nesvačily section, Bohemia.

Material: 26 complete flattened specimens and a dozen incomplete rhabdosomes.

Etymology: praecox, Latin, meaning premature.

Diagnosis: Slender, gently ventrally curved Bohemograptus with straight, 0.4-0.55 mm wide proximal part comprising 3-4 thecae; straight sicula with slightly expanded aperture and dorsal wall extending outwards from the straight dorsal outline of the proximal part.

Description: The ventrally arcuate rhabdosome, at least $100 \mathrm{~m}$ long, possesses a straight proximal part comprising 3-4 thecae. Rhabdosome widens gradually from $0.4-0.5 \mathrm{~mm}$ at th 1 , $0.42-0.55 \mathrm{~mm}$ at th $3,0.5-0.65 \mathrm{~mm}$ at th $5,0.6-0.85 \mathrm{~mm}$ at th 10 , and $0.75-1.0 \mathrm{~mm}$ at th 20 , to distal maximum of $0.8-1.2 \mathrm{~mm}$. The straight sicula, $1.25-1.7 \mathrm{~mm}$ long, is $0.3-0.4 \mathrm{~mm}$ wide across the slightly expanded aperture and furnished with a short virgella and moderately developed rutellum. The sicular apex attains about level of the aperture of the $0.95-1.3 \mathrm{~mm}$ long th 1 . The thecae are straight tubes, overlapping for one-third their length in the proximal part of the rhabdosome and for half their length distally. Even thecal apertures are perpendicular to the thecal axis or slightly everted. The 2TRD varies between 1.8 and $2.1 \mathrm{~mm}$ 
251 in $90 \%$ of specimens, lower values are common in proximal thecae whereas high values are

252 typical in distal thecae. Extreme 2TRD values of 1.6-2.6 mm have been observed rarely in

253 both proximal and distal thecae.

254

255

Remarks: B. praecox sp. nov. resembles the Ludfordian Bohemograptus garratti Rickards et

256

257

258

259

260

261

262

263

264

265

266

267

268

269

270

271

272

273

274

275

al. in having a gracile, arcuate rhabdosome but differs in the more open rhabdosome

curvature, straighter proximal part, and shorter sicula with expanded aperture and dorsal wall that protruded outwards from an otherwise straight proximal dorsal outline. The proximal thecae of $B$. praecox are less inclined and, in general, less widely spaced with 2 TRD about 2 $\mathrm{mm}$ as opposed to $2.5 \mathrm{~mm}$, which is a common value in $B$. garratti. Other bohemograptids can be differentiated by their more robust, generally less openly curved, and fish-hook shaped rhabdosomes with slightly ventrally curved sicula and more strongly overlapping thecae.

Juvenile rhabdosomes of B. praecox, composed of sicula and initial thecae, can be distinguished from juvenile Neodiversograptus nilssoni (Lapworth) by the absence of a dorsal spine on the sicular aperture and by the sicular apex attaining the level of th 1 aperture.

Bohemograptus has been considered a typical indicator of Ludlow strata. Rickards and Wright (1999) assumed, quite reasonably, that the ancestor of the Gorstian B. bohemicus ,,must occur in the lowest levels of the nilssoni Biozone or high in the underlying ludensis Biozone“. This is exactly the range of $B$. praecox sp. nov. The similar morphology of juvenile $B$. praecox and N. nilssoni suggests speciation from a common ancestor in the course of the ludensis Biozone.

\section{Conclusions}

Organic-rich, subsequently bleached shales, uncommon non-graptolite fossils (see Fig. 2) and absence of bioturbation in the Nesvačily section indicate a stable, deep-water, off-shore 
276 setting with low and occasional oxygenation of a soft bottom, i.e. an environment, in which

277 graptolites flourished. The graptolite record is enhanced locally by the high sedimentation

278 rates and limited input of pyroclastic material. Continuous sedimentation revealed a

279 succession of origination events of principal graptolite taxa employed in determination of the

280 Wenlock-Ludlow boundary strata world-wide. Bohemograptus appeared as early as in the

281 uppermost Wenlock upper ludensis Biozone (FAD of Bohemograptus praecox sp. nov.). It is

282 succeeded by the FAD of Neodiversograptus nilssoni indicating the base of the Ludlow

283 nilssoni Biozone. B. praecox is later accompanied and subsequently replaced by B. bohemicus

284 associated with Uncinatograptus uncinatus. Speciation within the Bohemograptus plexus

285 continued in the middle nilssoni Biozone when the robust, short-ranging B. butovicensis

286 evolved from B. bohemicus. Colonograptus colonus made its lowest occurrence in the middle

287 part of the nilssoni Biozone together with the LAD of C. gerhardi. The monograptid fauna is

288 also accompanied by abundant and diverse plectograptids, which broadly correspond with

289 species recorded, so far, only from erratic boulders of Baltic origin (Maletz 2008, 2010) and

290 from boreholes in Poland (Kozłowska-Dawidziuk 1995). The conodont Kockelella ortus

291 absidata found in a single limestone sample in the lower-middle part of the nilssoni Biozone

292 is consistent with a stratigraphic interval between the $O z$. bohemica and $K$. crassa conodont

293 biozones. The present data from Nesvačily has shown that the base of the nilssoni graptolite

294 Biozone is a very suitable high-resolution correlation base for the Ludlow Series despite the 295 rather problematic value of the current GSSP.

\section{Acknowledgements}


301

302

303

304

305

306

307

308

309

310

311

312

313

314

315

316

317

318

319

320

321

322

323

324

325

of Geology of the CAS (RVO 67985831), Š.M. and Z.T. acknowledge support provided by

the Strategic plan of the Czech Geological Survey. Our thanks are due to anonymous referees for helpful comments on an earlier version of the manuscript. This is a contribution to the IGCP project No. 591.

\section{References}

Aldridge, R.J., Siveter, David, J., Siveter, Derek, J., Lane, P.D., Palmer, D. and Woodcock, N.H. 2000. British Silurian stratigraphy. Geological Conservation Review Series. Joint Nature Conservation Committee, Peterborough.

Bouček, B. 1936. La faune graptolithique du Ludlovien inferieur de la Bohême. Bulletin international de l'Académie de Science de la Bohême, 46(16): 1-26.

Calner, M., and Jeppsson, L. 2003. Carbonate platform evolution and conodont stratigraphy during the middle Silurian Mulde event, Gotland, Sweden. Geological Magazine, 140: $173-203$.

Holland, C.H., and Bassett, M.G. 1989. A Global Standard for the Silurian System. National Museum of Wales Geological Series, 10: 1-325.

Koren', T.N., and Sujarkova, A.A. 2004. The Ludlow (Late Silurian) neocucullograptid fauna from the southern Tien Shan, Kyrghizstan. Alcheringa, 28: 333-387.

Kozłowska-Dawidziuk, A. 1995. Silurian retiolitids of the East European Platform. Acta Palaeontologica Polonica, 40: 261-326.

Kozłowska-Dawidziuk, A., Lenz, A.C., and Štorch, P. 2001. Upper Wenlock and lower Ludlow (Silurian), post-extinction graptolites, Všeradice section, Barrandian area, Czech Republic. Journal of Paleontology, 75: 147-164.

Kř́žz, J., Dufka, P., Jaeger, H., and Schönlaub, H.P. 1993. The Wenlock/Ludlow Boundary in 
the Prague Basin (Bohemia). Jahrbuch der Geologischen Bundesanstalt, Wien, 136: 809839.

Maletz, J., 2008. Retiolitid graptolites from the collection of Hermann Jaeger in the Museum für Naturkunde, Berlin (Germany). I. Neogothograptus and Holoretiolites. Paläontologische Zeitschrift, 82: 285-307.

Maletz, J. 2010. Retiolitid graptolites from the collection of Hermann Jaeger II: Cometograptus, Spinograptus and Plectograptus. Paläontologische Zeitschrift, 84: 501522.

Manda, Š., Štorch, P., Slavík, L., Frýda, J., Kříž, J., and Tasáryová, Z. 2012. The graptolite, conodont and sedimentary record through the late Ludlow kozlowskii Event (Silurian) in the shale-dominated succession of Bohemia. Geological Magazine, 149: 507-531.

Přibyl, A. 1983. Graptolite biozones of the Kopanina and Přídolí formations in the Upper Silurian of central Bohemia. Časopis pro mineralogii a geologii, 28: 149-167.

Rickards, R.B., and Wright, A.J. 1999. Evolution of the Ludlow (Silurian) graptolite genus Bohemograptus Prribyl 1936. Proceedings of the Yorkshire Geological Society, 52: $313-$ 320.

Riva, J.F.V., Koren', T.N., and Rickards, R.B. 2001. Polonograptus Tsegelnjuk, 1976 (Graptolithina): proposed designation of P. podoliensis Pribyl, as the type species. Bulletin of Zoological Nomenclature, 58: 291-293.

Slavík, L. 2014. Revision of the conodont zonation of the Wenlock-Ludlow boundary in the Prague Synform. Estonian Journal of Earth Sciences, 63: 305-311.

Štorch, P., Manda, Š., and Loydell, D.K. 2014. The Early Ludfordian leintwardinensis graptolite Event and the Gorstian-Ludfordian boundary in Bohemia (Silurian, Czech Republic). Palaeontology, 57: 1003-1043.

Tsegelnyuk, P.D. 1976. Late Silurian and Early Devonian Monograptidae of the south-west 
351

352

353

354

355

356

357

358

359

360

361

362

363

364

365

366

367

368

369

370

371

372

373

374

375

376

Ukrainian East European platform, 91-133. In Eocambrium and Lower Palaeozoic palaeontology and stratigraphy of southwestern part of Eastern European Platform. Naukova Dumka, Kiev. (in Russian)

Urbanek, A., and Teller, L. 1997. Graptolites and stratigraphy of the Wenlock and Ludlow series in the East European Platform. Palaeontologia Polonica, 56: 23-57.

White, D.E. 1981. The base of the Ludlow Series in the graptolitic facies. Geological Magazine, 118: 566.

\section{Figure captions}

Fig. 1. Location map of the Ordovician-Devonian Prague Synform within the Czech

Republic; location of the Nesvačily area in the south-western part of the Silurian outcrop area and location of the Nesvačily section on a topographic map. GPS coordinates of the section: $49^{\circ} 53^{\prime} 13.18^{\prime \prime} \mathrm{N}, 14^{\circ} 06^{\prime} 55.07^{\prime \prime} \mathrm{E}$.

Fig. 2. Lithology, graptolite record and non-graptolite body fossils across the WenlockLudlow boundary interval in Nesvačily; including sample intervals referred to in the text.

Fig. 3. Minute plectograptid graptolites from the Nesvačily section. (A) Neogothograptus ornatus Maletz, PŠ 3805. (B) Neogothograptus eximinassa Maletz, PŠ 3721. (C)

Spinograptus clathrospinosus (Eisenack), broad apertural spines with reticulo-fusellar structures, PŠ 3652. (D) Neogothograptus balticus (Eisenack), PŠ 3699. (A, D) nilssoni Biozone, (B, C) ludensis Biozone. Scale bar equals $1 \mathrm{~mm}$.

Fig. 4. Graptolites from the Nesvačily section. (A) Spinograptus spinosus (Wood), PŠ 3695.

(B) Neogothograptus eximinassa Maletz, PŠ 3724. (C) Neogothograptus balticus (Eisenack), 
377 PŠ 3688. (D) Spinograptus munchi (Eisenack), PŠ 3656. (E) Neogothograptus ornatus

378 Maletz, PŠ 3811. (F, K) Neodiversograptus nilssoni (Lapworth); (F) PŠ 3804, slender bipolar

379 form; (K) PŠ 3833b, unipolar early form, see also juvenile rhabdosome with long antivirgellar

380 spine. (G) Plectograptus robustus Obut and Zaslavskaya, PŠ 3799. (H) Bohemograptus

381 bohemicus (Barrande), PŠ 3662. (I) Spinograptus clathrospinosus (Eisenack), PŠ 3823. (J)

382 Plectograptus macilentus (Törnquist), PŠ 3822. (L, O-P) Bohemograptus praecox sp. nov.;

383 (L) PŠ 3801, (O) PŠ 3760, (P) PŠ 3746. (M) Valentinagraptus aff. simplex Piras, PŠ 3832 b.

384 (N, Q, W) Bohemograptus butovicensis (Bouček); (N) PŠ 3827, (Q) PŠ 3691, (W) PŠ 3825.

385 (R) Colonograptus gerhardi (Jaeger), PŠ 3718. (S) Uncinatograptus uncinatus (Tullberg), PŠ

386 3745. (T) Colonograptus colonus (Barrande), PŠ 3828. (U) Colonograptus ludensis

387 (Murchison), PŠ 3726. (V) Pristiograptus frequens Jaekel: PŠ 3738. (A, C, E-Q, S-T, V-W)

388 nilssoni Biozone, (B, D, R, U) ludensis Biozone. Scale bar equals $1 \mathrm{~mm}$.

390 Fig. 5. (A, C) Bohemograptus butovicensis (Bouček); (A) -PŠ 3691, immature specimen; (C)

391 PŠ 3820b, large rhabdosome without sicula, mesial part broken out. (B, D-E) Bohemograptus

392 praecox sp. nov.; (B) PŠ 3773, holotype; (D) PŠ 3779, (E) PŠ 3712. (B, D-E) ludensis

393 Biozone, (A, C) nilssoni Biozone. Scale bars equal $1 \mathrm{~mm}$. 


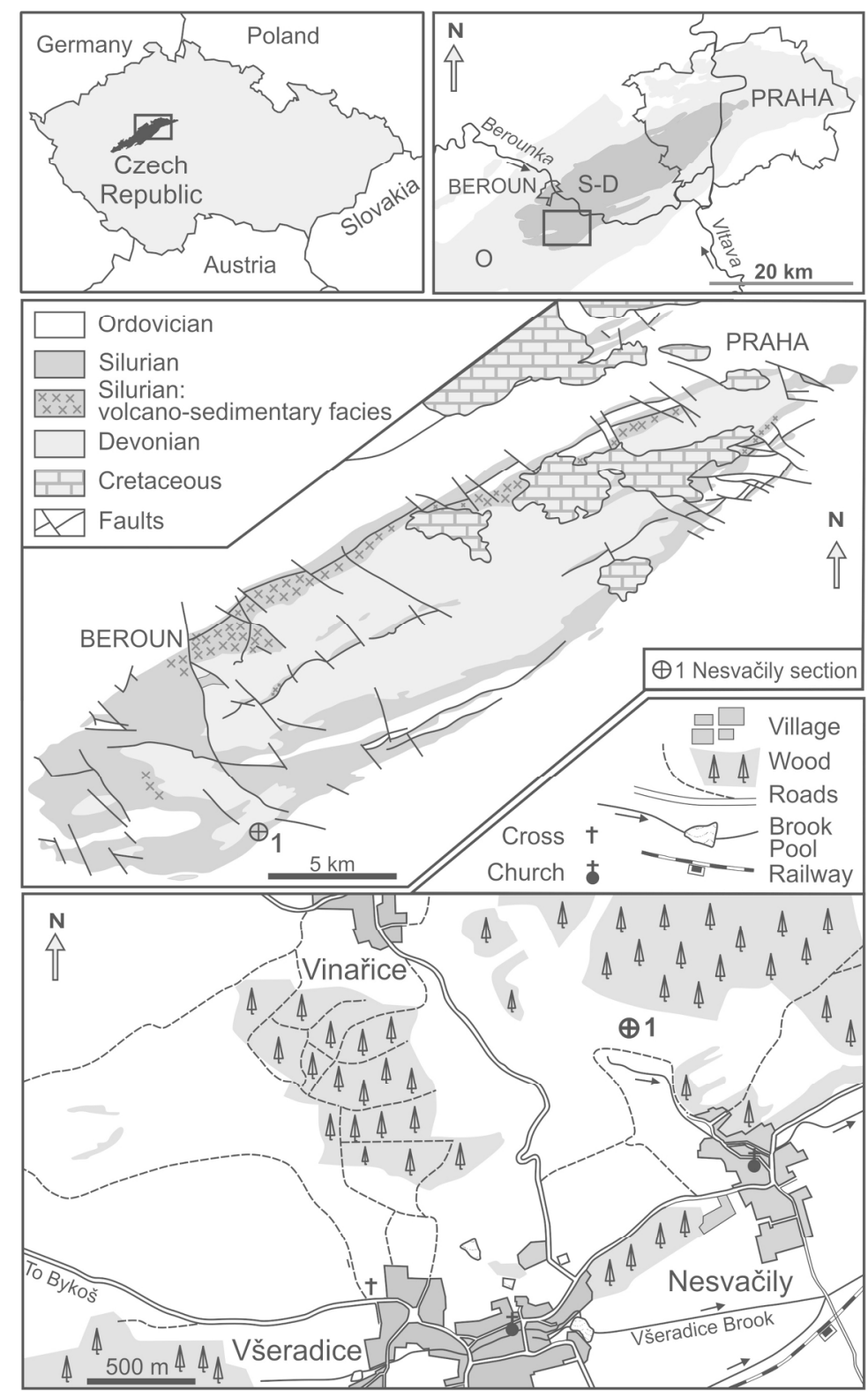

Fig. 1. Location map of the Ordovician-Devonian Prague Synform within the Czech Republic; location of the Nesvačily area in the south-western part of the Silurian outcrop area and location of the Nesvačily section on a topographic map. GPS coordinates of the section: 49²53'13.18" N, $14^{\circ} 06^{\prime} 55.07^{\prime \prime} \mathrm{E}$.

$139 \times 227 \mathrm{~mm}(300 \times 300 \mathrm{DPI})$ 


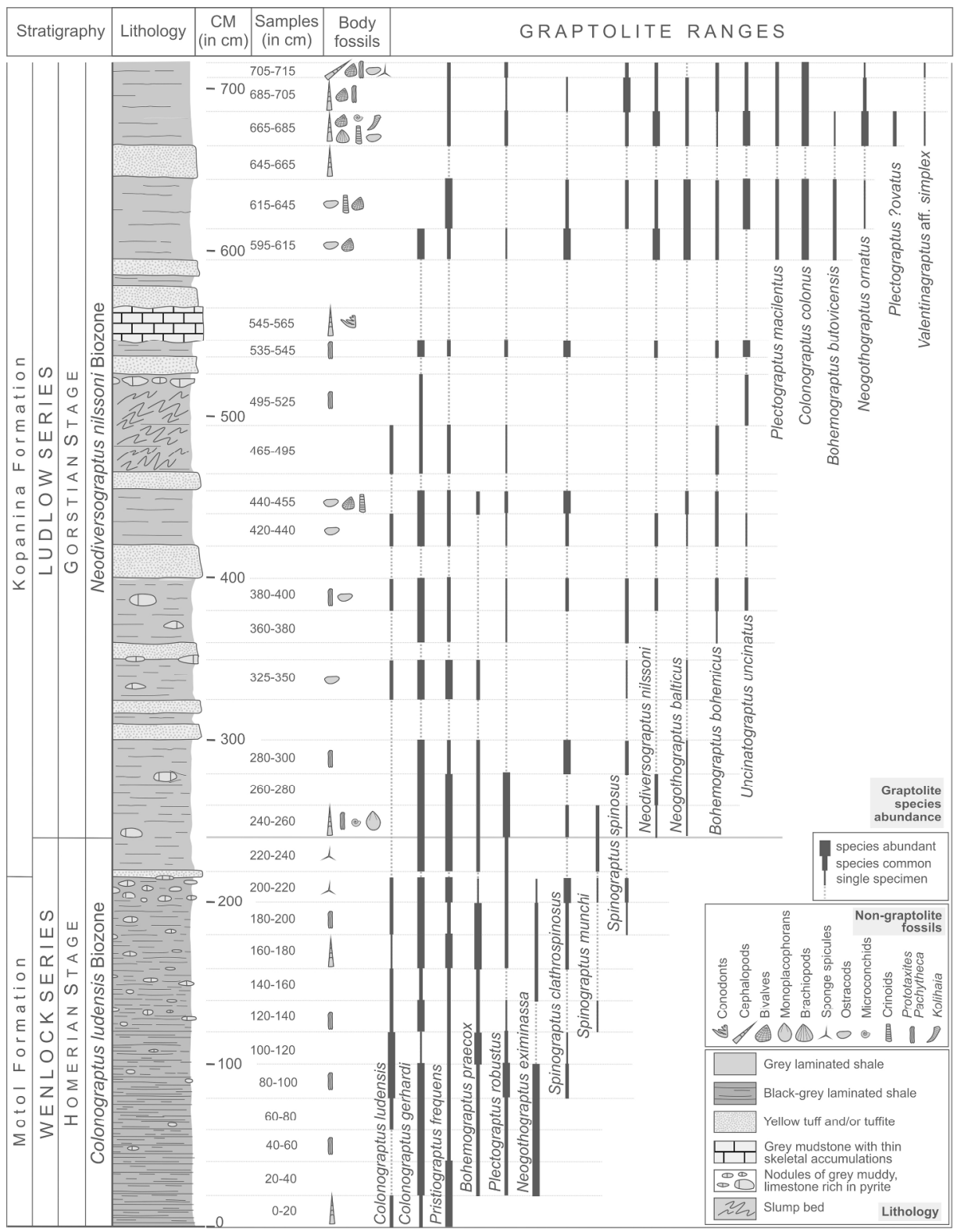

Fig. 2. Lithology, graptolite record and non-graptolite body fossils across the Wenlock-Ludlow boundary interval in Nesvačily; including sample intervals referred to in the text. $234 \times 301 \mathrm{~mm}(300 \times 300 \mathrm{DPI})$ 

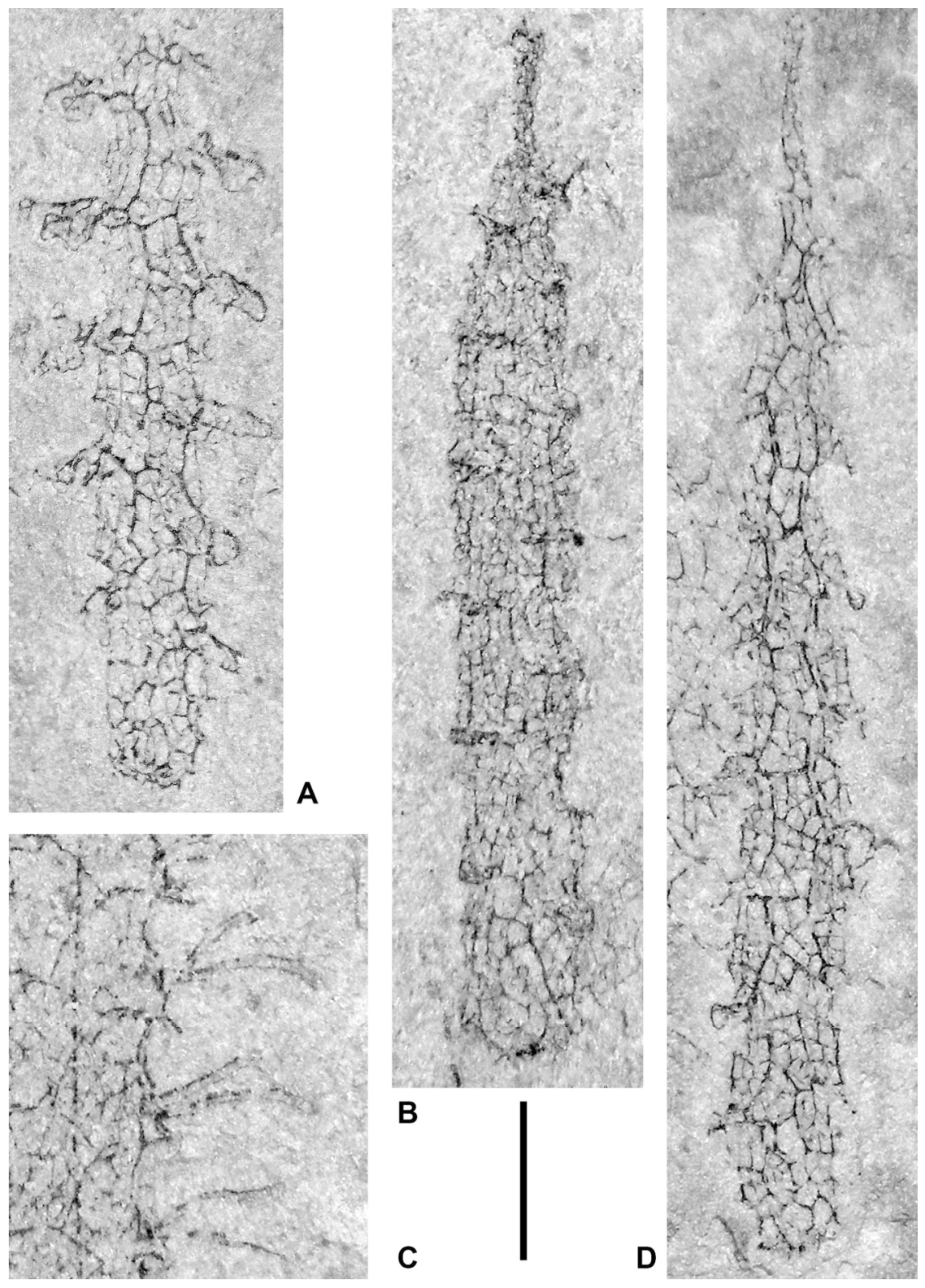

Fig. 3. Minute plectograptid graptolites from the Nesvačily section. (A) Neogothograptus ornatus Maletz, PŠ 3805. (B) Neogothograptus eximinassa Maletz, PŠ 3721. (C) Spinograptus clathrospinosus (Eisenack), broad apertural spines with reticulo-fusellar structures, PŠ 3652. (D) Neogothograptus balticus (Eisenack), PŠ 3699. ( $A, D)$ nilssoni Biozone, $(B, C)$ ludensis Biozone. Scale bar equals $1 \mathrm{~mm}$. $119 \times 167 \mathrm{~mm}(300 \times 300 \mathrm{DPI})$ 


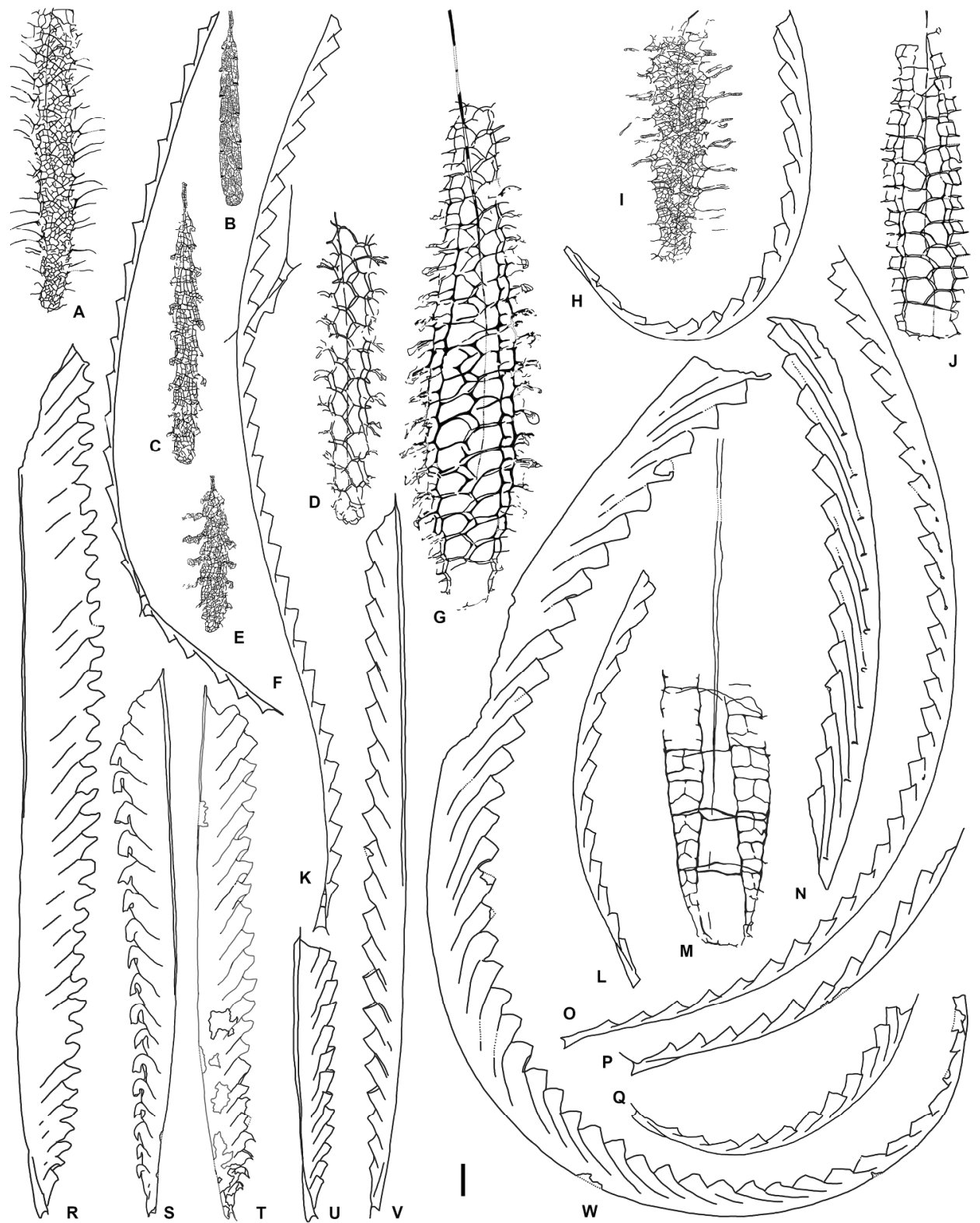

Fig. 4. Graptolites from the Nesvačily section. (A) Spinograptus spinosus (Wood), PŠ 3695. (B) Neogothograptus eximinassa Maletz, PŠ 3724. (C) Neogothograptus balticus (Eisenack), PŠ 3688. (D) Spinograptus munchi (Eisenack), PŠ 3656. (E) Neogothograptus ornatus Maletz, PŠ 3811. (F, K) Neodiversograptus nilssoni (Lapworth); (F) PŠ 3804, slender bipolar form; (K) PŠ 3833b, unipolar early form, see also juvenile rhabdosome with long antivirgellar spine. (G) Plectograptus robustus Obut and Zaslavskaya, PŠ 3799. (H) Bohemograptus bohemicus (Barrande), PŠ 3662. (I) Spinograptus clathrospinosus (Eisenack), PŠ 3823. (J) Plectograptus macilentus (Törnquist), PŚ 3822. (L, O-P) Bohemograptus praecox sp. nov.; (L) PŠ 3801, (O) PŠ 3760, (P) PŠ 3746. (M) Valentinagraptus aff. simplex Piras, PS 3832b. (N, Q, W) Bohemograptus butovicensis (Bouček); (N) PŠ 3827, (Q) PŠ 3691, (W) PŠ 3825.

(R) Colonograptus gerhardi (Jaeger), PŠ 3718. (S) Uncinatograptus uncinatus (Tullberg), PŠ 3745. (T) Colonograptus colonus (Barrande), PŠ 3828. (U) Colonograptus ludensis (Murchison), PŠ 3726. (V) Pristiograptus frequens Jaekel: PŠ 3738. ( $A, C, E-Q, S-T, V-W$ ) nilssoni Biozone, $(B, D, R, U$ ) ludensis Biozone. Scale bar equals $1 \mathrm{~mm}$. 
$229 \times 290 \mathrm{~mm}(300 \times 300 \mathrm{DPI})$

https://mc06.manuscriptcentral.com/cjes-pubs 


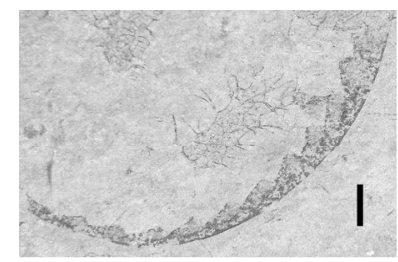

$$
\begin{aligned}
& \text { A } \\
& \text { B }
\end{aligned}
$$

A

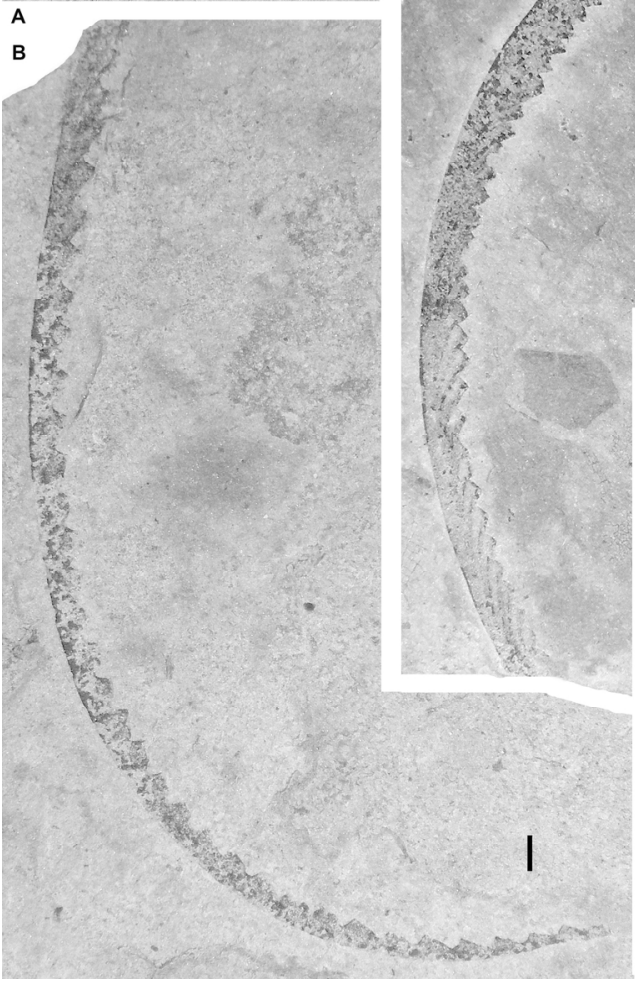

c

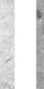

(
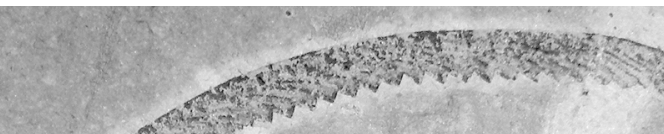